\title{
Income smoothing through loan loss provisions in south and Eastern European banks*
}

\author{
Albulena Shala ${ }^{1}$, Valentin Toçi ${ }^{2}$, Skender Ahmeti ${ }^{3}$
}

\begin{abstract}
This study provides empirical evidence on income smoothing from the banking sector in nine South-Eastern Europe (SEE) countries for the period 2005-2014 by applying a number of methodological approaches. First, by using a sample of 321 banks this paper confirms our first hypothesis that banks in the SEE region use loan loss provisions (LLPS) to smooth their incomes. Second, by dividing the loan loss provision into its two components (discretionary and non-discretionary,) the study provides new evidence on the effects of loan loss provisions components on growth in bank lending. The results clearly prove our second hypothesis that the components of LLPS do matter on growth in bank lending. Third, this paper estimates the use of loan loss provisions for capital management by banks. The empirical results do not support the hypothesis of capital management for SEE banks. The novelty of this paper, unlike other works, is the inclusion of SEE countries.
\end{abstract}

Key words: loan loss provisioning, South and Eastern European banks, income smoothing, capital management hypothesis, discretionary component, nondiscretionary component

JEL classification: G21, M10, M41, M49

\footnotetext{
* Received: 25-10-2020; accepted: 04-12-2020

1 Teaching Assistant, University of Prishtina "Hasan Prishtina", Faculty of Economics, 10000 Prishtine, The Republic of Kosovo. Scientific affiliation: banking, corporate finance and institutional economic. Phone: +38344422 122. E-mail: albulena.shala@uni-pr.edu. ORCID ID: https://orcid.org/0000-0002-8403-4536.

2 Full Professor, University of Prishtina "Hasan Prishtina", Faculty of Economics, 10000 Prishtine, The Republic of Kosovo. Scientific affiliation: financial economics, banking, institutional economics. Phone: +38344376 907. E-mail: valentin.toci@uni-pr.edu. ORCID ID: https:// orcid.org/0000-0003-1062-918X. (Corresponding author).

3 Full Professor, University of Prishtina "Hasan Prishtina", Faculty of Economics, 10000 Prishtine, The Republic of Kosovo. Scientific affiliation: accounting, managerial accounting and cost accounting. Phone: +38344313 130.E-mail: skender.ahmeti@uni-pr.edu.
} 


\section{Introduction}

Income smoothing in the banking sector is a process in which banks use high earnings to create buffers that are used in periods of low earnings. Recent studies have examined bank managers' using of LLPs to smooth their incomes and manage regulatory the ratio of capital (such as Lobo and Yang, 2001; Shrieves and Dahl, 2003; Kanagaretnam et al., 2004a; Ozili and Outa, 2018; Habib et al., 2020). As a result, the income smoothing in the banking sector has made earnings less volatile over time. If potential perceived performance is projected to be low, managers have an opportunity to move current earnings towards the future to keep down the possibility of poor future performance, also, managers' concerns about their job security create an incentive to use LLPs for income smoothing. In doing so, it allows them to 'save' earnings for possible use in the future. Managers are motivated to use their discretion over accruals to smooth the volatility of performance. Consequently, banks will smooth their incomes by using LLPs when their incomes are high, and lowering the LLPs if their incomes are low (Kanagaretnam et al., 2003; Ozili and Outa, 2018; Ozil, 2019).

Another important matter in which the recent studies have focused is whether banks use LLPs to manage regulatory capital requirements. The capital management hypothesis says that banks use the LLPs to manage with their regulatory capital (e.g., Pérez et al., 2008; Leventis et al., 2011; Beccalli and Poli, 2015; Curcio and Hasan, 2015).

The main purpose of this paper is to test the possibility of using LLPs by banks in CEE countries. Therefore, this paper will answer three important hypotheses, based on the literature review. The first hypothesis of this paper is that LLPs are used by banks for income smoothing in SEE countries (Albania, Bulgaria, Bosnia and Herzegovina, Croatia, Kosovo, Serbia, Montenegro, Macedonia, Romania and Slovenia). Since LLPs have a non-discretionary (NDISC) component and a discretionary component (DISC), the study separates the discretionary part of the provisions so that it can be examined whether bank managers used the discretionary component to manage their incomes for the period 2005-2014. So, the second hypothesis, is that LLP components have an effect on growth in bank lending in SEE countries. The third hypothesis is that LLPs are not used for capital management for countries in the sample.

For the following purposes, our study is very important. First, there is no study that tested the income smoothing hypothesis for SEE banks, so our study aims to shed some light on whether SEE banks used LLPs to smooth their incomes. Second, including this region this research will also contribute to the income smoothing and capital management literature. Our study contributes to the extant literature through empirical findings. First, our findings confirm that banks in SEE countries use LLPs to smooth their incomes. Second, by controlling for components of LLP, 
we contribute to the literature that examines the effects of these components on loans growths among banks. The results find that both of them have an effect on loan growth. Third, by controlling for capital management hypothesis, our study contributes to literature on bank capital regulation.

This topic is of particular importance for banks supervisors and banks' external auditors, as it helps them to understand better if the managers of banks did use LLPs for their objectives.

The rest of the paper is organized as follows. The following section reviews previous literature. Section three describes methodological issues related to income smoothing (the analytical methods used to separate LLP discretionary and non-discretionary components, a description of the models used by previous authors to test income smoothing). Section four data, includes sample selection and description of variables in details. The last two sections (five and six) discuss the results of the study from the needs for prevention of misuse of LLPs.

\section{Literature review}

Research on LLPs remains a very important aspect of banking research, for four key purposes. First, LLPs is a significant discretionary accrual at the disposal of bank directors. Second, LLPs has a strong impact on the margin of bank interest and therefore affects average bank earnings. Three, LLPs is related to micro-prudential supervision by bank regulators and is related to the informativeness of accounting disclosures needed by accounting standard-setters in financial reports (Ozili, 2017).

LLPs are a fairly large big accrual for commercial banks, and therefore, for many activities LLPs are used by managers. In recent years, research in the banking sector focuses on the using of LLPs for income smoothing and capital management as well as the relationship of LLPs to the respective countries' macroeconomic conditions (Majnoni and Cavallo, 2001; Lobo and Yang, 2001; Bikker and Metzemakers, 2005; Bouvatier and Lepetit, 2008; Fonseca and González, 2008; Packer and Zhu, 2012; Bonin and Kosak, 2013; Bouvatier et al., 2014; Olszak et al., 2017; Caporale et al., 2018; Ozili, 2018).

Income smoothing is a subject that was discussed very early by different authors and continues to be explored even today, especially after the recent financial crisis. More recently, several empirical studies in commercial banks, particularly American banks, have revealed various smoothing practices.

Kanagaretnam et al. (2003) analyses the Fudenberg-Tirole model's projections by evaluating how bank managers smooth their incomes through LLPs. Their empirical analysis shows that managers use LLPs to smooth their incomes. Their 
results suggest that when actual earnings are relatively low (high), but predicted relatively high (low) potential unmanaged earnings, managers may release (build) reserves. In reality, bank managers are "borrowing" earnings from the future. According to Kanagaretnam et al. (2004), bank managers appraise LLPs to represent changes in expected future loan losses. Their research underlines that managers are using the LLPs to meet more than one target results. Kanagaretnam et al. (2004a) findings evidence that US banks use discretionary loan loss provisions to reduce earnings fluctuations and to manage their capital. These findings are compatible with the income smoothing hypothesis to keep down income volatility. Bushman and Williams (2012) study the case of forward-looking LLPs and find that banks use their discretion in forward-looking provisioning to smooth their incomes. According to Bushman and Williams (2012), loan loss provisioning is a primary accounting method that directly affects the stability and cyclicality of bank earnings. Using U.S. data, Bushman and Williams (2015) find out that trying of bank to postpone provisions on losses in the balance sheet will contribute more to systemic risk and the effect is greater during economic downturns. According to Bushman and Williams (2015) decreases in transparency will contribute to increased consumer confusion regarding to weaken market discipline over risktaking behavior. During the global financial crisis, Morris et al. (2016) studied the economic determinants and value significance of the LLP of US banks. They find that discretionary provisions are used for smoothing and signaling, but smoothing happens more often.

There are also many studies for European countries. The income-smoothing hypothesis was tested by Norden and Stoian (2014) based on quarterly data from 85 Dutch banks covering the period from 1998 to 2012. Norden and Stoian (2014) note that general provisions are not tax-deductible in the Dutch tax law system as in many other EU countries. In addition, Dutch banks' general LLPs are not recognized as Tier Two capital. They find that banks use LLPs, in fact, banks are changing LLPs to prevent fluctuations in their assets weighted against risk. Pérez et al. (2008) examined data from financial statements for 142 Spanish banks, they emphasize that banks must reach minimum regulatory capital standards, which means that income smoothing through LLPs may result from accounting practices intended to meet those requests. According to Pérez et al. (2008) in many countries' bankers have broad flexibility in deciding the sum of LLPs to accumulate and LLPs offer a unique tool for banks to smooth their incomes. They verified the income smoothing hypothesis in Spanish banks through general and specific LLPs, but they did not find the using of LLPs for capital management. Therefore, the authors mention that the introduction of the transparent statistical provision, which is separately reported by banks on a line in their income statements, contributes to improving the quality of accounting data. Working on a panel of European commercial banks, Bouvatier and Lepetit (2008) figure out that banks use LLPs to smooth their incomes in all the different countries that they include. 
Leventis et al. (2011) analyzed the usage of LLPs for income smoothing and capital management hypothesis between 91 listed European banks that approve IFRS (International Financial Reporting Standards) standards, and figure out evidence that LLPs are used by early and late adopters of IFRS to smooth their incomes, but this behavior is low after the IFRS. They have also found that, overall, while riskier banks participate more in income smoothing using LLPs prior to IFRS implementation, these banks' propensity to engage in identical behavior in the postIFRS regime has been significantly lower. They have not found any evidence to indicate that LLPs are used for capital management.

Curcio and Hasan (2015) analyzed the Euro and non-Euro Area cases and find that banks outside the Euro Area use LLPs as an income-smoothing tool during the financial crisis years 2007-2010, but not to manage their capital ratios or to transfer private information to the market. They have found no similar evidence for credit institutions in the Euro Area. Curcio et al. (2017) also examined the use of discretionary LLPs, during the time when Euro Area banks faced a declining credit standard and a significant decline in profitability, when banks were subject to a new form of stricter supervision, called the 2010 and 2011 European Banking Authority (EBA) stress testing exercises. Curcio et al. (2017) find proof for income smoothing through LLPs at banks that were subject of EBA. In addition, during the years 2004-2012, Skała (2015) analyzed 179 commercial banks in 11 Central European countries, providing empirical evidence that banks in Central European countries use LLPs to smooth their incomes. Skała (2015) stated that LLPs directly have an effect on the net profit amount and thereby retain earnings which are a portion of bank capital. According to Skała (2015) income smoothing through LLPs is closely connected to capital adequacy and in the economic downturn Central European banks create additional reserves, leading to higher LLPs. Also, Ozili and Thankom (2018) finds that European banks use LLPs to smooth their incomes.

Taktak et al. (2010a) also conducted a regression analysis study, using a data set of 278 banks operating in OECD countries. The results indicate that commercial banks tend to adhere to real income smoothing more often than to artificial ones by selling shares instead of managing provisions on loan losses. According to Taktak et al. (2010) artificial smoothing results from manipulating or controlling accounting figures, meanwhile real smoothing, results from manipulating or controlling real activities. Bikker and Metzemakers (2005) emphasize that banks are setting higher levels of reserves aside during good years, for example, as a precaution - provisions are increased in good years for use in lean ones. The capital-to-asset ratio (CAP) is negatively correlated with provisions, supporting the hypotheses of capital management predicting higher provisioning when the capital ratio is relatively low. Fonseca and Gonzalez (2008) analyzed a sample from 41 countries. They also show proof of income smoothing via LLPs. According to Fonseca and Gonzalez (2008), bank income smoothing in the form of LLPs varies from one country to another 
depending on factors such as investor protection, disclosure, regulation, financial structure and development, etc.

The results are mixed among Asian studies. Some of them find that Chinese banks engaged in income smoothing (Packer and Zhu, 2012; Bonin and Kosak, 2013; Wu et al.,2015; Curcio et al., 2017; Ozili, 2018; Vishnani et al., 2019). However, Bryce et al. (2015) find that Vietnamese banks did not engage in income smoothing.

Present studies also show that LLPs is related to capital management. According to Beatty and Liao (2014) the motivations of banks to use accounting discretion to manage regulatory capital ratio can rely on how costly it is to hold extra equity capital. Beatty et al. (1995) concluded that while accrual decisions for managers are complicated by other capital-raising activities, LLPs are used as capitalmanagement mechanism. Capital management hypothesis claims that bank executives use LLPs to reduce the potential regulatory costs correlated with the violation of capital adequacy requirements (Ahmed et al., 1999; Fonseca and Gonzales, 2008). The hypothesis of capital management foresee that the capital ratio is negatively connected to LLPs because bank managers with low capital ratios can raise them by charging more LLPs, to keep down regulatory costs required by regulations on capital adequacy ratios (Lobo and Yang, 2001). Ahmed et al. (1999) claim that, because bank regulators expect banks to retain minimum regulatory capital for the risk they face, bank managers have some ability to manipulate the amount of LLPs so that they can fulfill minimum regulatory capital standards, if LLPs are included in the measurement of minimum regulatory capital ratios. According to Kanagaretnam et al. (2004), while bank managers with low regulatory capital have stimulations to increase LLPs because bank regulators require banks to keep minimum regulatory capital ratios (CAP). They suggest that the coefficient on CAP should be negative. Pérez et al. (2008) also emphasis that banks can use LLPs to modify retained earnings, thereby managing their regulatory capital, in order to meet their targets for regulatory capital. However, their results show that, contrary to the capital management hypothesis predictions, the coefficient of CAP is positive and statistically significant. Bikker and Metzemakers (2005) argue that the CAP ratio is negatively correlated with provisions, supporting the hypotheses of capital management predicting higher provisioning when the capital ratio is relatively small. According to Taktak et al. (2010) a negative sign of the CAP indicates that the lower the capital ratio, the higher the LLP will be. According to the authors, this finding supports the claim that well-capitalized banks enter less risky activities.

Olszak (2012) analyses quarterly data for Poland from 1998 through 2009. There is no statistically significant relation between LLPs and CAP ratio, so the analysis indicates the rejection of the hypothesis of capital management. According to Olszak (2012) this could be a result of Polish commercial banks' very favorable capital positioning. Caporale et al. (2018) examined data from a panel of 400 Italian banks to investigate the determinants of LLP between 2001 and 2015. Caporale et 
al. (2018) find proof that the CAP ratio and the LLPs had a negative relationship. According to Taktak et al. (2010) a negative sign of CAP indicates that the lower the capital ratio, the higher the LLPs will be. According to the authors, this finding supports the claim that well-capitalized banks enter less risky activities. But, Aristei and Gallo (2019) do not support the hypothesis of income smoothing and capital management and indicate that LLPs by Italian banks are mainly motivated by nondiscretionary factors relevant to expected credit risk during the crisis time. Also, Ozil, (2017) for a bank sample of selected Western European banking institutions find that banks use LLPs for income smoothing and capital management.

Abu-Serdaneh (2018) analysis all listed Jordanian banks and covers the 2005-2014 period. The findings show that there is no definitive evidence to support the use of provisions by Jordanian banks to smooth their incomes, manage capital ratios or engage in pro-cyclical behavior. Soedarmono et al. (2017) investigates whether LLPs in Islamic banks is procyclical from a study of Islamic banks worldwide from 1997 to 2012. A closer analysis further documents that Islamic banks also use LLPs for capital management, where reserves and provisions for loan losses are inflated as bank capitalization declines.

\section{Methodology}

There are two ways to test income smoothing. First, the first one, testing the relation between the variables of LLPs with earnings before taxes and provisions (EBTPs) and the second way, by dividing the LLPs into its two components and then continuing to test the relationship between the discretionary part (DISC)and the EBTPs. According to Bouvatier and Lepetit (2008), two components of LLPs are mentioned in the literature. The first one, named the non-discretionary component (NDISC), is done in a bank's loan portfolio to cover expected future credit losses. The second part, named the discretionary component (DISC), is attributed to the usage of LLPs for goals of management. Bouvatier and Lepetit (2008) in their equation included EBTPs to test income smoothing and CAP ratio to test the capital management hypothesis. The DISC component according to Bouvatier and Lepetit (2012), is primarily related to non-performing loans (NPLs). Also, Wahlen (1994) and Kanagaretnam et al. (2004) splits LLPs into two components: the nondiscretionary and the discretionary. The authors note that information about nondiscretionary provision for loan losses may allow investors to assess the discrete components of the LLPs.

Consistent with earlier studies, a two-stage method is adopted for testing of income smoothing through the discretionary component of LLPs (Kanagaretnam, et al., 2004; Kwak et al., 2009; Taktak et al., 2010; Leventis et al., 2011; Bouvatier et al., 2014; Othman and Mersni, 2014; Shawtari et al., 2015; Bryce et al., 2015; Aristei 
and Gallo, 2019). The non-discretionary component of LLP is estimated in the first stage using the model in equation (1), so that the discretionary component is isolated from the total of LLPs. In keeping with earlier studies, following variables are used to estimate the non-discretionary component of LLPs:

$$
\begin{aligned}
L L P_{i t}= & \beta_{0}+\beta_{1} \Delta N P L_{i t}+\beta_{2} L_{i t}+\beta_{3} C A P+\beta_{4} E B T P+\beta_{5} N P L_{i t}+ \\
& +\beta_{6} G D P_{i t}+\varepsilon_{i t}
\end{aligned}
$$

where:

$L L P S$ - Loan loss provisions over total bank assets for bank $i$ at time $t$.

$\triangle N P L$ - The change in non-performing loans deflated by beginning total loan.

$L O A N S / T A$ - Growth rate of net loans to total assets.

$E B P T$ - Ratio of earnings before taxes and LLPs divided by total asset.

$N P L$ - Ratio of non-performing loans divided by total loans.

$G D P$ - Real growth of GDP.

According to Bouvatier and Lepetit (2008 \& 2012), Aristei and Gallo (2019) in non-discretionary component of LLPs are considered variables which statistically significant. If a variable is not significant or has the opposite sign from expected, the variable associated with this coefficient is dropped (Bouvatier and Lepetit, 2012). Whereas the past equation estimates the non-discretionary portion of LLP, in equation (2) the discretionary component is estimated as residual. Also, following Jin et al. (2018) the residuals of Equations (1) are computed as DISC:

$$
D I S C_{i t}=L L P_{i t}-\hat{\beta}_{1} N D I S C_{i t}
$$

where:

$L L P S$ - Loan loss provisions over total bank assets for bank $i$ at time $t$.

DISC - Discretionary portion of LLP.

NDISC - The non-discretionary portion of LLP.

According to Bouvatier and Lepetit (2012), the advantages of this definition are double, it tends to be applied for each dataset, paying little attention to the importance of variables catching the discretionary behavior. These discretionary and non-discretionary components are used to test the impact of provisioning behaviors on bank loans fluctuations. According to Bouvatier and Lepetit (2008) the variable NDISC it includes all the variables which may explain the nondiscretionary component.

In the second stage, the relationship between the discretionary component and other variables is being tested. The independent variables in equation (3) hereinafter presents variables hypothesized to impact the discretionary component. Following 
many other authors (Kanagaretna et al., 2004 \& 2004a; Kwak et al., 2009; Bouvatier and Lepetit, 2012; Norden and Stoian, 2014; Shawtari et al., 2015) in this way, directly was tested the relationship between EBTPs and DISC:

$$
\begin{aligned}
D I S C_{i t}= & \beta_{0}+\beta_{1} \Delta N P L_{i t}+\beta_{2} L_{i t}+\beta_{3} C A P+\beta_{4} E B T P+\beta_{5} N P L_{i t}+ \\
& +\beta_{6} G D P_{i t}++\beta_{7} L D_{i t}+\beta_{8} S i z e_{i t}+\varepsilon_{i t}
\end{aligned}
$$

where:

DISC - Discretionary portion of LLP.

$\triangle N P L$ - The change in non-performing loans deflated by beginning total loan.

$L O A N S / T A-$ Growth rate of net loans to total assets.

$C A P$ - Capital to total assets.

$E B P T$ - Ratio of earnings before taxes and LLPs divided by total asset.

$N P L$ - Ratio of non-performing loans divided by total loans.

$G D P$ - Real growth of GDP.

$L D$ - Total loans to total deposits.

Size - Logarithm of total assets.

If the coefficient of EBTPs is positive and significant with discretionary component, the result shows that banks have used LLPs for income smoothing.

Bouvatier and Lepetit (2008) show that provisions relating to non-discretionary loan loss exacerbate a pro-cyclical effect because higher non-discretionary provisions keep down growth in bank loans. By comparison, DISC, particularly those associated to income smoothing behavior, has no significant effect on the growth of bank loans. Within various banking systems, though, the provisioning activities and their subsequent impact on lending growth will vary considerably. Their findings indicate that the non-discretionary portion of LLP has a negative and significant impact on growth in bank lending in all the countries that they listed, with larger frequency for developing countries excluding Japan.

Based on the models used in the Bouvatier and Lepetit (2012) studies, in equation 4 it was tested for the effects of the non-discretionary and discretionary components on lending growth:

$$
L_{i t}=\alpha+\beta_{1}+\beta_{2} N_{D I S C}+\beta_{3} D_{i S C_{i t}}+\beta_{3} D_{i t}+\beta_{4} E_{i t}+\beta_{5} S I Z E_{i t-1}+\varepsilon_{i t}
$$

where:

$L-$ Growth rate of net loans to total assets.

DISC - Discretionary portion of LLP. 
NDISC - The non-discretionary portion of LLP.

$D$ - Growth rate of deposits.

$E$ - Capital to total assets.

$E B P T$ - Ratio of earnings before taxes and LLPs divided by total asset.

SIZE - Logarithm of total assets.

In this paper countries from South and East Europe are involved. The database contains information of active commercial banks that reported financial statements to Bankscope database for the period 2005-2014 in 9 countries (Albania, Bulgaria, Bosnia and Herzegovina, Croatia, Kosovo, Serbia, Montenegro, Macedonia, Romania and Slovenia). Table 1 shows the number of banks involved for each country.

Table 1: Number of banks included in the sample

\begin{tabular}{|l|c|c|}
\hline \multicolumn{1}{|c|}{ Country } & Symbol & Number of banks \\
\hline Albania & AL & 20 \\
\hline Bosnia and H. & BA & 44 \\
\hline Bulgaria & BG & 40 \\
\hline Croatia & HR & 80 \\
\hline Macedonia & MK & 24 \\
\hline Serbia & RS & 49 \\
\hline Slovenia & SI & 41 \\
\hline Kosovo & KV & 8 \\
\hline Monetenegro & ME & 15 \\
\hline Total & & 321 \\
\hline
\end{tabular}

Source: Authors'

In next section we will explain the variables that are included in models. 


\section{Empirical data and analysis}

Models include several control variables. Definitions of variables are presented in Table 2.

Table 2: Summary of the variables

\begin{tabular}{|c|c|l|}
\hline Variable & Predicted sign & \multicolumn{1}{|c|}{ Definition } \\
\hline$L L P S$ & $+/-$ & Loan loss provisions over total bank assets for bank iat time $t$ \\
\hline$\Delta \mathrm{NPL}$ & $+/-$ & $\begin{array}{l}\text { The change in non-performing loans deflated by beginning } \\
\text { total loan. }\end{array}$ \\
\hline $\mathrm{L}$ & $+/-$ & Growth rate of net loans to total assets. \\
\hline $\mathrm{E}$ & $+/-$ & Capital adequacy ratio. \\
\hline $\mathrm{D}$ & $+/-$ & Growth rate of deposits. \\
\hline EBPT & + & $\begin{array}{l}\text { Ratio of earnings before taxes and LLPs divided by total } \\
\text { asset. }\end{array}$ \\
\hline$G D P$ & - & Real growth of GDP \\
\hline$C A P$ & - & Capital to total assets \\
\hline$N P L$ & $+/-$ & Ratio of non-performing loans divided by total loans \\
\hline$L O A N S / T A$ & $+/-$ & Total loans divided by total assets \\
\hline$S I Z E$ & $+/-$ & Logarithm of total assets \\
\hline$L D$ & $+/-$ & Total loans to total deposits \\
\hline$N D I S C$ & - & The non-discretionary portion of LLP. \\
\hline$D I S C$ & - & Discretionary portion of LLP. \\
\hline
\end{tabular}

Note: Bank-level data are from the Bankscope database. GDP growth, inflation and unemployment data are from the World Bank development indicators.

Source: Authors'

The most important variable in this research is $E B T P_{i t}$, as it measures income smoothing. For the income smoothing hypothesis, as suggested by many authors (Wahlen, 1994; Collins et al., 1995; Beatty et al., 1995; Ahmed et al., 1999; Jin et al., 2018) should be a positive relationship between EBTPs and LLPs. Specifically, banks can use LLPs according to the income-smoothing hypothesis to smooth their incomes by overstating (understating) LLPs when incomes are expected to be high/ low (Aristei and Gallo, 2019).

A growing share of non-performing loans (NPLs) in the loan portfolio of banks signifies greater risks affecting both the liquidity and profitability of banks. Moreover, it represents a weakening balance sheet of banks (Ghosh, 2015). According to Škarica (2014) the high levels of NPLs are becoming a growing concern, provided the experiences from previous financial crises indicate that a lasting recovery needs 
a "clean-up" in the financial sector. According to previous literature, NPLs may be introduced as a bad output (or, in terms of the profit function, an expense that reduces total profits) into the production function of the bank (García-Alcober et al., 2019). Bouvatier and Lepetit (2012) used the ratio of NPLs divided by total assets at the end of the year $t\left(N P L_{i t}\right)$ and the first difference of $N P L_{i t}\left(T N P L_{i t}=N P L_{i t}-N P L_{i t-1}\right)$ as explanatory variables. Bouvatier and Lepetit (2008) argue that NPLs are a good indicator of the expected loss identified by banks for their loan portfolio.

Also, the ratio of NPLs to gross loans at the end of the year $t\left(N P L_{i t}\right)$ is a good evidence of the risk of non-payment on banks' loans (Kim and Kross, 1998; Lobo and Yang, 2001; Bouvatier and Lepetit 2008; Skała, 2015).

Empirical studies that test the capital management hypothesis focus on the negative relationship between the coefficients of LLP and CAP ratio (Collins et al., 1995; Kim and Kross, 1998; Ahmed et al., 1999; Lobo and Yang, 2001; Anandarajan et al., 2007; Leventis et al., 2011; Curcio and Hasan, 2015; Simper et al., 2019).

Loan to deposit ratio $\left(L D_{i t}\right)$ has been used as proxy for external financing in studies. Following Kanagaretnam et al. (2003 \& 2004a) the ratio of total loans to total deposits is used as a measure of banks' need for external financing. If the loan portfolio of a bank is larger than its total deposits, it would need to borrow to finance its lending portfolio. Banks are typically financed by customer deposits, but they require sufficient equity resources to meet bank regulatory capital ratios. Many researchers (such as Kwak et al., 2009; Shawtari et al., 2015) used the $L D_{i t}$ as an indicator for external financing of the banking sector. According to Shawatari et al. (2015) if the ratio is high, the bank needs external funding, and thus there is a tendency for the banks to record low discretionary LLPs to show low figure out credit risks and higher reported profits to draw more deposits from the borrowers and give the depositors assurance to allocate their funds to the banks. A lower level of the ratio of $L D_{i t}$ represents a lower dependence on wholesale funding which means that the bank is less market constrained in its asset growth (Cucinelli, 2015).

Another control variable, which measures the size of the bank, is the natural logarithm of total assets (Size). Based on many studies (such as Anandarajan et al., 2007; Pérez et al., 2008; Leventis et al., 2011) larger banks might have higher levels of activity than small banks, so they have higher LLPs because they are required to take greater activity and risk into account. From the other hand, considering opportunities for portfolio diversification, becoming more likely to be exploited in a larger credit portfolio, the relation between bank size and the usage of LLPs may be predicted to be negative. Leventis et al. (2011) also suggest that relatively smaller banks often hold higher LLPs ratio. This can be due to less effective diversification of credit risk policies. Meanwhile, according to Tran et al. (2019) large banks tend to have more stable activities and better risk diversification capacity. Large banks are expected to report smaller amounts of DISC, while small banks are more likely 
to have deficiencies in internal control and are more likely to correct previously reported earnings. In addition, larger banks may be subject to stricter regulatory scrutiny and monitoring.

Variable $\left(L_{i t}\right)$ is the ratio of total loans divided by total assets and represents a measure for the risk profile of the bank (Taktak et al., 2010). Bouvatier and Lepetit (2008) also include the risk of default for the overall credit portfolio, calculated by the ratio of net loans divided by total assets $\left(L_{i t}\right)$.

Moreover, Bouvatier and Lepetit (2008 \& 2012), Soedarmono et al. (2012) study the effect of discretionary vs. non-discretionary LLPs on bank lending. Both find that non-discretionary provisions amplify credit fluctuations. Therefore, both components of LLPs are relevant to determine growth in lending.

GDP is the rate of growth of gross domestic product in year t. It is aims to catch the effect of macroeconomic conditions on LLPs (Laeven and Majnoni, 2003; Bikker and Metzemakers, 2005; Taktak et al., 2010; Aristei and Gallo, 2019). Coherent with recent methodological literature (Ghosh, 2007; Bouvatier and Lepetit, 2008; Fonseca and Gonzalez, 2008; Leventis et al., 2011; Bushman and Williams, 2012; Aristei and Gallo, 2019) a significant and negative coefficient of the growth rate of GDP confirms provide evidence on the strong pro-cyclical pattern of LLPs.

We implemented a panel data approach using a model of fixed effects to test three hypotheses, that for the presence of income smoothing, capital management and the effect of components of LLPs on bank lending growth, in which we included variables usually applied in other studies. To examine the effect of these components of LLPs on lending behavior, first, the dependent variable (LLPs/TA) was analyzed with the independent variables included in the first equation.

A positive and significant result between EBTPs and LLPs would be compatible with the income smoothing hypothesis, implying that in periods of strong profitability banks raise their provisioning, whilst declines in profits contribute to the use of the earlier generated loan loss reserve buffers. It is important to note that EBTPs has a positive relationship but insignificant with LLPs. The positive sign of the coefficient of the EBTPs/ TA variable is consistent with the results of other authors (such as Bikker and Metzemakers 2005; Pérez et al., 2008; Fonseca and Gonzales 2008; Bouvatier and Lepetit, 2008 \& 2012; Taktak et al., 2010). This is also the first way to test income smoothing directly through the positive coefficient of EBTPs/TA.

In addition, banks can use LLPs for capital management. The total capital ratio (CAP/TA) is used to capture this behavior for SEE banks. Findings show that the capital ratio coefficient is positive and statistically significant, contrary to the predictions of the capital management hypothesis. This confirms our third hypothesis that banks in SEE countries did not use the LLPs to manage their 
capital. Therefore, is no statistical evidence to indicate that banks employ capital management through LLPs. This means that banks in SEE were well capitalized and have no need to use LLPs to manage their capital. Our findings, however, are similar to that reported by Fonseca and Gonzalez, (2008), Pérez et al. (2008), etc. According to Pérez et al. (2008) this indicates that the absence of capital management implies that banks adopt the strategy of covering expected losses with provisions and unexpected losses with capital.

The coefficient of variable NPL_TA is positive and significant (Tab. 3). According to Kanagaretnam et al. (2004) an increase in NPLs is likely to result in an increase in the LLPs. This is to say, with a higher level of beginning NPLs, banks should have to make higher LLPs. The risk of default (LOANS/TA) for the overall credit portfolio was also included in model following Bouvatier and Lepetit (2008), measured by the ratio of loans divided by total assets.

The ratio of loans to total asset is negative and significant (Tab. 3). After controlling for the rest of the variables, the business cycle does not affect bank's LLPs. Also, the variable of NPL_change is not statistically significant (Tab. 3). GDP growth is negative but is not statistically significant.

Table 3: The decomposition of loan loss provisions (Model 1)

\begin{tabular}{|l|r|c|c|}
\hline \multicolumn{1}{|c|}{ LLPs/TA } & \multicolumn{1}{c|}{ Coefficient } & $(t$-value $)$ & $\mathrm{P}>|\mathrm{t}|$ \\
\hline EBTPs/TA & 1.783 & 1.17 & 0.242 \\
\hline CAP/TA & $0.046^{* *}$ & 2.25 & 0.026 \\
\hline NPL/TA & $11.961^{* * *}$ & 7.10 & 0.000 \\
\hline LOANS/TA & $-0.029^{* *}$ & -2.58 & 0.010 \\
\hline GDPgr & -0.020 & -0.95 & 0.341 \\
\hline NPL_change & -0.015 & -0.23 & 0.819 \\
\hline cons & -0.085 & -0.07 & 0.945 \\
\hline Nr. of observations $=336$ & \multicolumn{3}{|l}{} \\
\hline
\end{tabular}

Notes: Significant at: $* 10, * * 5$ and $* * * 1$ percent levels. The results are from Eq. (1)

Variable definitions: LLPs/TA: loan loss provisions/total assets, CAP/TA: equity/total assets, NPL/TA: non-performing loans/gross loan, NPL_change: change in non-performing loans, EBTPs/TA: current earnings before tax and provisions/total assets, GDP growth rate.

Source: Author's calculations

The calculation of DISC and NDISC component of LLP is also estimated at equation (1). In NDISC component of provisions will include all those variables that are significant with the dependent variable (LLPs/TA) in equation (1). There are three significant variables: loans to total assets, capital to total assets and non-performing 
loans to total assets. LLP's discretionary portion is the difference between LLPs and the non-discretionary portion. Then was tested for the presence of income smoothing by taking the DISC component of LLPs as a dependent variable (Tab. 4).

Table 4: Income smoothing in SEE countries (Model 3)

\begin{tabular}{|l|c|c|c|}
\hline \multicolumn{1}{|c|}{ DISC } & Coefficient & (t-value) & $\mathrm{P}>|\mathrm{t}|$ \\
\hline EBTPs_TA & $3.124 * *$ & 2.01 & 0.045 \\
\hline CAPITAL/TA & $-0.976 * * *$ & -43.21 & 0.000 \\
\hline LOANS/TA & $-1.032 * * *$ & -79.63 & 0.000 \\
\hline NPL_TA & $11.517 * * *$ & 6.67 & 0.000 \\
\hline TA_log & $-1.238 * * *$ & -3.25 & 0.001 \\
\hline GDPgr & -0.023 & -1.09 & 0.276 \\
\hline NPL_change & 0.031 & 0.45 & 0.656 \\
\hline LOANS/DEPOSIT & -0.002 & -0.63 & 0.528 \\
\hline cons & $16.207 * * *$ & 3.13 & 0.002 \\
\hline Nr. of observations $=336$ & \multicolumn{3}{l}{} \\
\hline
\end{tabular}

Notes: Significant at: $* 10, * * 5$ and $* * * 1$ percent levels. The results are from Eq. (3)

Source: Author's calculations

With regard to the discretionary behavior, the findings are consistent with the assumption that banks use LLPs to smooth their incomes. Indeed, the coefficient of EBTPs is significant and positive (Tab. 4). The results indicate that banks in SEE countries have made income smoothing through LLPs, more precisely with the DISCs component of LLPs, thus confirming our first hypothesis. That means LLPs are deliberately understated when earnings are expected to be low to reduce adverse effects of other earnings factors. From the other side, banks choose discretionary income-reducing accruals when the earnings are unusually high. Thus, under the behavior of income smoothing; banks choose LLPs to minimize the variance in reported earnings. This means that LLPs rise during a period of growth and decline during a period of contraction. With respect to discretionary behavior, results are consistent with the existing literature (Kanagaretnam et al., 2003; Laeven and Majnoni, 2003; Anandarajan et al., 2007; Fonseca and Gonzales, 2008; Kwak, et al., 2009; Leventis et al., 2011; Shawtari et al., 2015) as find that banks are using the discretionary component of LLP to smooth their incomes. This is the main question in this study.

The second hypothesis of this paper is to investigate the effect of the DISC (income smoothing) and the NDISC on growth in bank lending. The results show that both variables are negative and statistically significant. The finding is in line with Bouvatier and Lepetit (2008 \& 2012). 
Table 5: The effect of discretionary vs. non-discretionary LLPs on bank lending (Model 4)

\begin{tabular}{|l|r|c|c|}
\hline \multicolumn{1}{|c|}{ LOANSgr } & Coefficient & (t-value) & $\mathrm{P}>|\mathrm{t}|$ \\
\hline NDISC & $-4.054^{* * *}$ & -5.43 & 0.000 \\
\hline DISC & $-4.297^{* * *}$ & -5.89 & 0.000 \\
\hline DEPOSITSgr & $0.394^{* * *}$ & 5.52 & 0.000 \\
\hline TA_log & $-10.293^{* *}$ & -2.13 & 0.035 \\
\hline CAPITAL/TA & -0.441 & -1.31 & 0.192 \\
\hline cons & $139.883^{* *}$ & 2.02 & 0.045 \\
\hline Nr. of observations $=230$ & \multicolumn{3}{|l|}{} \\
\hline
\end{tabular}

Notes: Significant at: $* 10, * * 5$ and $* * * 1$ percent levels. The results are from Eq. (4b)

Source: Author's calculations

The coefficient of size is very important to highlight (Tab. 5). The estimation test shows the sign of variable of size is negative. This means that the discretionary component less emphatic at large banks. The results are similar with Cornett et al. (2009) and Shawtari et al. (2015) suggesting that smaller banks were more interested in the discretionary component. According to Cornett et al. (2009) larger banks are the ones most likely to be monitored by industry analysts. Likewise, whilst regulators are charged with maintaining the stability and soundness of the financial system as a whole, they at least appear to control the largest institutions more closely.

The coefficient associated with the growth rate of deposits is also significant and positive in all regressions. Shawtari et al. (2015) indicated that increased external financing requirements would inspire bankers to smooth their incomes. In order to draw more funds, managers are more encouraged to indulge in discretionary LLPs to smooth income and reduce instability. This confirms our second hypothesis which states that LLPs components have an effect on growth in bank lending in SEE countries.

\section{Results and discussion}

The results in the above section demonstrate the verification of three hypotheses. Firstly, the statistically significant coefficient of EBTP with DISC, indicates that banks in SEE countries use LLPs to smooth their incomes. Secondly, the positive coefficient of CAP ratio, explains that banks did not use the LLPs for capital management. Thirdly, the results clearly show that the components of LLPs do matter on growth in bank lending. 
Following the implementation of the legislation (IFRS and Basel II \& III) we would expect a decrease in the weight of the discretionary part of those provisions and, at the same time, an improvement in the portion of the provisions determined by credit risk considerations. However, providing a comprehensive collection of rules for LLPs does not preclude managers from decreasing volatility in earnings. The discussion on the usage of principles vs. comprehensive rules has drawn the attention of both accounting experts and setters of criteria (Pérez et al., 2008). The use of principles allows greater authority to managers, but this practice encourages authorities to ask for more comprehensive disclosure. Our paper indicates, though, that regulators ought to engage with accountants in an open discussion. It also reinforces the need for disclosure standards that increase bank transparency and control of the actions and incentives of bank managers by investors.

According to the results, banks in SEE countries did not use the LLPs for capital management. This shows that banks are well capitalized, but capital management motivations, do exist and may be a strong incentive for banks facing increased costs for violating capital requirements (Anandarajan et al., 2003).

We further jointly consider, in specification (4) the effect of the non-discretionary component and the total discretionary component of LLP on growth in lending. Both of them are negative and significant that is mean they are relevant to determine growth in lending (Bouvatier and Lepetit, 2008).

The evidence of these results for SEE countries should recommend increasing banking supervision by regulatory authorities and a higher quality of external audit.

Our analysis contributes to a growing body of literature in many ways: 1) prior studies focus on the level of a single country, reducing the generalization of findings. We use a specific dataset of 336 observations from 9 European countries; 2) this is the first study to test whether and how LLPs are being used in SEE countries for income smoothing and capital management.

\section{Conclusion}

There have been widely different reported management behavior characteristics in the banking loan loss provisioning literature, such as: income smoothing, capital management, etc. From the point of view of the banking regulators, LLPs should only be used to offset potential losses, but studies have also shown that LLPs are mainly used as an instrument for banks' capital management and income smoothing.

Our first hypothesis was to test whether bank managers use LLPs for income smoothing. Furthermore, the second hypothesis was to examine whether provisioning 
practice amplifies growth in bank lending. In the absence of empirical literature on this topic in SEE countries, for a sample of banks with unbalanced data during the period 2005-2014, this study conducted research on income smoothing through LLPs. Income smoothing in regression model was verified through the relation between EBTP and LLPs and the relation between DISC component of the LLPs with EBTPs coefficient. Therefore, after separating the LLPs into the two components, the income smoothing was tested through the DISC component of the LLPs, the EBTPs coefficient has a positive sign and significant in favor of income smoothing. Also, results show that the DISC and NDISC components have a negative and significant effect on bank lending; therefore, both components are relevant to explain credit fluctuations. This common characteristic allows us to ensure that banking regulators could consider the beneficial aspects of a dynamic provisioning system. Our third hypothesis was to test the use of LLPs for capital management. Results also show that banks in SEE countries didn't use LLPs for capital management.

To the best information, this study represents the first effort of conducting research on income smoothing and effects of LLPs on growth on bank lending in SEE countries. The empirical evidence for income smoothing in SEE banks lay out here has substantial policy implications for national regulators, auditors, and investors, and the public at large. Despite the considerable effort exerted in conducting the study in order to ensure that the objectives of the study were met and research questions were answered, one of the limitations of the study is the small sample size. This study for the regulators can be very helpful, warning them to make effective policy restricting the intensive use of discretion over LLPs to manage their incomes. In addition, when reviewing, auditing, and expressing their opinion on financial statements, an auditor can pay more attention to the LLPs estimation policy. Future research could investigate other credit risk factors that influence the level of discretionary provisions among SEE banks. Also, future research could investigate whether discretionary provisions are influenced by the risk culture of banks SEE. Future studies should also include periods after 2014 in order to investigate the impact of IFRS 9 on the decrease or increase of the use of LLPs for income smoothing in SEE countries.

\section{References}

Ahmed, A. S., Takeda, C., Thomas, S. (1999) "Bank loan loss provisions: a reexamination of capital management, earnings management and signaling effects", Journal of accounting and economics, Vol. 28, No.1, pp. 1-25, https:// doi.org/10.1016/S0165-4101(99)00017-8.

Anandarajan, A., Hasan, I., Lozano-Vivas, A. (2003) "The role of loan loss provisions in earnings management, capital management, and signaling: The Spanish experience", Advances in International Accounting, Vol. 16, pp. 45-65, https://doi.org/10.1016/S0897-3660(03)16003-5. 
Anandarajan, A., Hasan, I., McCarthy, C. (2007) "Use of loan loss provisions for capital, earnings management and signalling by Australian banks", Accounting \& Finance, Vol. 47, No. 3, pp. 357-379, https://doi.org/10.1111/j.1467- 629x. 2007.00220.x.

Abu-Serdaneh, J. (2018) "Bank loan-loss accounts, income smoothing, capital management, signaling and procyclicality", Journal of Financial Reporting and Accounting, Vol. 16, No. 4, pp. 677-693, https://doi.org/10.1108/JFRA-062016-0041.

Aristei, D., Gallo, M. (2019) "Loan loss provisioning by Italian banks: Managerial discretion, relationship banking, functional distance and bank risk", International Review of Economics \& Finance, Vol. 60, pp. 238-256, https:// doi.org/10.1016/j.iref.2018.10.022.

Beccalli, E., Poli, F. (2015) Bank Risk, Governance and Regulation, Springer.

Beatty, A. et al. (1995) "Managing financial reports of commercial banks: The influence of taxes, regulatory capital, and earnings", Journal of accounting research, Vol. 33, No. 2, pp. 231-261, https://doi.org/10.2307/2491487.

Beatty, A., Liao, S. (2014) "Financial accounting in the banking industry: A review of the empirical literature", Journal of Accounting and Economics, Vol. 58, Issues: 2-3, pp. 339-383, https://doi.org/10.1016/j.jacceco.2014.08.009.

Bikker, J.A., Metzemakers, P.A. (2005) "Bank provisioning behaviour and procyclicality", Journal of international financial markets, institutions and money, Vol. 15, No. 2, pp. 141-157, https://doi.org/10.1016/j.intfin.2004.03.004.

Bonin, J., Kosak, M. (2013) "Loan/Loss Provisioning in Emerging Europe: Precautionary or ProCyclical?” No. 2013-010, Wesleyan University, Department of Economics, https://doi.org/10.1787/888932359891.

Bouvatier, V., Lepetit, L. (2008) "Banks' procyclical behavior: Does provisioning matter?", Journal of international financial markets, institutions and money, Vol. 18, No. 5, pp. 513-526, https://doi.org/10.1016/j.intfin.2007.07.004.

Bouvatier, V., Lepetit, L. (2012) "Effects of loan loss provisions on growth in bank lending: some international comparisons", Economie internationale, Vol. 132, pp. 91-116, https://doi.org/10.2139/ssrn.1663580.

Bouvatier, V., Lepetit, L., Strobel, F. (2014) "Bank income smoothing, ownership concentration and the regulatory environment", Journal of Banking \& Finance, Vol. 41, No. 1, pp. 253-270, https://doi.org/10.1016/j.jbankfin.2013.12.001.

Bushman, R.M., Williams, C.D. (2012) "Accounting discretion, loan loss provisioning, and discipline of banks' risk-taking”, Journal of Accounting and Economics, Vol. 54, No. 1, pp. 1-18, https://doi.org/10.1016/j.jacceco.2012.04.002.

Bushman, R. M., Williams, C. D. (2015) "Delayed expected loss recognition and the risk profile of banks", Journal of Accounting Research, Vol. 53, No. 3, pp. 511-553, https://doi.org/10.1111/1475-679x.12079. 
Bryce, C. et al. (2015) "An analysis of loan loss provisioning behaviour in Vietnamese banking”, Finance Research Letters, Vol. 14, pp. 69-75, https://doi.org/10.1016/j. frl.2015.05.014.

Caporale, G. M. et al. (2018) "Loan loss provisions and macroeconomic shocks: Some empirical evidence for italian banks during the crisis", Finance Research Letters, Vol. 25, pp. 239-243, https://doi.org/10.1016/j.frl.2017.10.031.

Collins, J. D. et al. (1995) "Bank differences in the coordination of regulatory capital, earnings and taxes", Journal of Accounting Research Vol. 33, No. 2, pp. 263-292, https://doi.org/10.2307/2491488.

Cornett, M. M., McNutt, J. J., Tehranian, H. (2009) "Corporate governance and earnings management at large US bank holding companies", Journal of Corporate finance, Vol. 15, No. 4, pp. 412-430, https://doi.org/10.1016/j.jcorpfin.2009.04.003.

Curcio, D., Hasan, I. (2015) "Earnings and capital management and signaling: the use of loan- loss provisions by European banks", The European Journal of Finance, Vol. 21, No.1, pp. 26-50, https://doi.org/10.1080/1351847x.2012.762408.

Curcio, D., De Simone, A., Gallo, A. (2017) "Financial crisis and international supervision: New evidence on the discretionary use of loan loss provisions at Euro Area commercial banks", The British Accounting Review, Vol. 49, No. 2, pp. 181-193, https://doi.org/10.1016/j.bar.2016.09.001.

Cucinelli, D. (2015) "The impact of non-performing loans on bank lending behavior: evidence from the Italian banking sector", Eurasian Journal of Business and Economics, Vol. 8, No. 16, pp. 59-71, https://doi.org/10.17015/ejbe.2015.016.04.

Fonseca, A.R., Gonzalez, F. (2008) "Cross-country determinants of bank income smoothing by managing loan-loss provisions", Journal of Banking \& Finance, Vol. 32, No. 2, pp. 217-228, https://doi.org/10.1016/j.jbankfin.2007.02.012.

Habib, A. et al. (2020) "Financial statement comparability, earnings smoothing and loan-loss provisioning in banking", Earnings Smoothing and Loan-Loss Provisioning in Banking, http://dx.doi.org/10.2139/ssrn.3622974.

García-Alcober, M. et al. (2019) "Risk-taking behavior, earnings quality, and bank performance: A profit frontier approach", BRQ Business Research Quarterly, https://doi.org/10.1016/j.brq.2019.02.003.

Ghosh, A. (2015) "Banking-industry specific and regional economic determinants of non- performing loans: Evidence from US states", Journal of financial stability, Vol. 20, pp. 93-104, https://doi.org/10.1016/j.jfs.2015.08.004.

Jin, J. Y., Kanagaretnam, K., \& Liu, Y. (2018) "Banks' funding structure and earnings quality”, International Review of Financial Analysis, Vol. 59, pp. 163178, https://doi.org/10.1016/j.irfa.2018.08.009.

Kanagaretnam, K., Lobo, G. J., Mathieu, R. (2003) "Managerial incentives for income smoothing through bank loan loss provisions", Review of Quantitative Finance and Accounting, Vol. 20, No. 1, pp. 63-80, https://doi.org/10.2139/ ssrn.292674. 
Kanagaretnam, K., Lobo, G. J., \& YANG, D. H. (2004) “Joint tests of signaling and income smoothing through bank loan loss provisions", Contemporary Accounting Research, Vol. 21, No. 4, pp. 843-884, https://doi.org/10.1506/ udwq-r7b1-a684-9ecr.

Kanagaretnam, K., Lobo, G. J., Mathieu, R. (2004a) "Earnings management to reduce earnings variability: Evidence from bank loan loss provisions", Review of Accounting and Finance, Vol. 3, No. 1, pp. 128-148, https://doi.org/10.1108/ eb043399.

Kim, M.S., Kross, W. (1998) "The impact of the 1989 change in bank capital standards on loan loss provisions and loan write-offs", Journal of Accounting and Economics, Vol. 25, No. 1, pp. 69-99, https://doi.org/10.1016/s01654101(98)00015-9.

Kwak, W., Lee, H. Y., Eldridge, S. W. (2009) "Earnings management by Japanese bank managers using discretionary loan loss provisions", Review of Pacific Basin Financial Markets and Policies, Vol. 12, No. 1, pp. 1-26, https://doi. org/10.1142/s0219091509001526.

Laeven, L., Majnoni, G. (2003) "Loan loss provisioning and economic slowdowns: too much, too late?, Journal of financial intermediation, Vol. 12, No. 2, pp. 178-197, https://doi.org/10.1016/s1042-9573(03)00016-0.

Leventis, S., Dimitropoulos, P. E., \& Anandarajan, A. (2011) "Loan loss provisions, earnings management and capital management under IFRS: The case of EU commercial banks", Journal of Financial Services Research, Vol. 40, No. 1-2, pp. 103-122, https://doi.org/10.1007/s10693-010- 0096-1.

Lobo, G.J., Yang, D.H. (2001) "Bank managers' heterogeneous decisions on discretionary loan loss provisions", Review of Quantitative Finance and Accounting, Vol. 16, No. 3, pp. 223-250, https://doi.org/10.1023/a:1011284303517.

Majnoni, G., Cavallo, M. (2001) "Do banks provision for bad loans in good times? Empirical evidence and policy implications", The World Bank, https://doi. org/10.1596/1813- 9450-2619.

Morris, R. D., et al. (2016) "The determinants and value relevance of banks' discretionary loan loss provisions during the financial crisis", Journal of Contemporary Accounting \& Economics, Vol. 12, No. 2, pp. 176-190, https:// doi.org/10.1016/j.jcae.2016.07.00.

Norden, L., Stoian, A., (2014) "Bank earnings management through loan loss provisions: a double-edged sword?", De Nederlandsche Bank Working Paper No. 404, http://dx.doi.org/10.2139/ssrn.2369798.

Olszak, M. (2012) "Procyclicality of Loan Loss Provisions - The Case of Poland", Advances in Business-Related Scientific Research Journal, Vol. 3, No. 2, pp. 20-32, Available at SSRN: <https://ssrn.com/abstract=2378305> [Accessed: 07.08.2020]. 
Olszak, M. et al. (2017) "What drives heterogeneity of cyclicality of loan-loss provisions in the EU?", Journal of Financial Services Research, Vol. 51, No. 1, pp. 55-96, https://doi.org/10.1007/s10693-015-0238-6.

Othman, H. B., Mersni, H. (2014) “The use of discretionary loan loss provisions by Islamic banks and conventional banks in the Middle East region: A comparative study", Studies in Economics and Finance, Vol. 31, No. 1, pp. 106-128, https:// doi.org/10.1108/sef- 02-2013-0017.

Ozili, P. K. (2017) "Discretionary provisioning practices among Western European banks", Journal of Financial Economic Policy, Vol. 9, No. 1, pp. 109-118, https://doi.org/10.1108/JFEP-07-2016- 0049.

Ozili, P. K. (2018) "Bank loan loss provisions, investor protection and the macroeconomy", International Journal of Emerging Markets, Vol. 13, No. 1, pp. 45-65, https://doi.org/10.1108/IJoEM-12-2016-0327.

Ozili, P. K. (2019) "Bank loan loss provisions, risk-taking and bank intangibles", Afro-Asian Journal of Finance and Accounting, Vol. 9, No. 1, pp. 21-39, https:// doi.org/10.1504/AAJFA.2019.096910.

Ozili, P. K., Outa, E. R. (2018) "Bank income smoothing in South Africa: role of ownership, IFRS and economic fluctuation", International Journal of Emerging Markets, Vol. 13, No. 5, pp. 1372-1394, https://doi.org/10.1016/j.bar.2018.03.001.

Ozili, P. K., Thankom G. A. (2018) "Income smoothing among European systemic and non- systemic banks", The British Accounting Review, Vol. 50, No. 5, pp. 539-558, https://doi.org/10.1016/j.bar.2018.03.001.

Packer, F., Zhu, H. (2012) "Loan loss provisioning practices of Asian banks", Bank for International Settlements, No. 375, http://dx.doi.org/10.2139/ssrn.2038215.

Pérez, D., Salas-Fumas, V., Saurina, J. (2008) "Earnings and capital management in alternative loan loss provision regulatory regimes", European Accounting Review, Vol. 17, No. 3, pp. 423-445, https://doi.org/10.1080/09638180802016 742.

Simper, R., Dadoukis, A., Cormac, B. B. (2019) "European bank loan loss provisioning and technological innovative progress", International Review of Financial Analysis, Vol. 63, pp. 119-130, https://doi.org/10.1016/j.irfa.2019.03.001.

Shawtari, F.A. et al. (2015) "The impact of efficiency on discretionary loans/finance loss provision: A comparative study of Islamic and conventional banks", Borsa Istanbul Review, Vol. 15, No. 4, pp. 272-282, https://doi.org/10.1016/j. bir.2015.06.002.

Shrieves, R.E., Dahl, D. (2003) "Discretionary accounting and the behavior of Japanese banks under financial duress", Journal of Banking \& Finance, Vol. 27, No. 7, pp. 1219-1243, https://doi.org/10.1016/s0378-4266(02)00252-2 02.

Skała, D. (2015) "Income Smoothing and Procyclicality of Loan Loss Provisions in Central European Banks", International Finance, Vol. 1, No. 18, pp. 25-46, https://doi.org/10.1111/1468-2362.12058. 
Soedarmono, W. et al. (2012) "Loan loss provisions and lending behaviour of banks: Asian evidence during 1992-2009, Available at SSRN: https://ssrn.com/ abstract=2049217 or http://dx.doi.org/10.2139/ssrn.2049217.

Soedarmono, W., Pramono, S. E., Tarazi, A. (2017) "The procyclicality of loan loss provisions in Islamic banks", Research in International Business and Finance, Vol. 39, pp. 911-919, https://doi.org/10.1016/j.ribaf.2016.05.003.

Škarica, B. (2014) "Determinants of non-performing loans in Central and Eastern European countries", Financial theory and practice, Vol. 38, No. 1, pp. 37-59, https://doi.org/10.3326/fintp.38.1.2.

Taktak, N. B., Zouari, S. B. S., Boudriga, A. (2010) "Do Islamic banks use loan loss provisions to smooth their results?", Journal of Islamic Accounting and Business Research, Vol.1, No. 2, pp. 114-127, https://doi.org/10.1108/17590811011086714.

Taktak, N. B., Shabou, R., Dumontier, P. (2010a) "Income smoothing practices: evidence from banks operating in OECD countries", International Journal of Economics and Finance, Vol. 2, No. 4, pp. 140-151, https://doi.org/10.5539/ ijef.v2n4p140.

Tran, D. V., Hassan, M. K., Houston, R. (2019) "Discretionary loan loss provision behavior in the US banking industry", Review of Quantitative Finance and Accounting, Vol. 55, pp. 1-41, https://doi.org/10.1007/s11156-019-00854-z.

Vishnani, S., Agarwal, S., Agarwalla, R., Gupta, S. (2019) "Earnings management, capital management and signaling behaviour of Indian banks", Asia-Pacific Financial Markets, Vol. 26, No. 3, pp. 285-295, https://doi.org/10.1007/ s10690-018-09265-x.

Wahlen, J.M. (1994) "The nature of information in commercial bank loan loss disclosures", The Accounting Review, Vol. 69, pp. 455-478, http://www.jstor. org/stable/248234.

Wu, M. W., Shen, C. H., Lu, C. H. (2015) "Do more foreign strategic investors and more directors improve the earnings smoothing? The case of China", International Review of Economics \& Finance, Vol. 36, pp. 3-16, https://doi. org/10.1016/j.iref.2014.11.003. 


\title{
Podešavanje prihoda kroz rezervacije za gubitke po kreditima u bankama Južne i Istočne Europe
}

\author{
Albulena Shala ${ }^{1}$, Valentin Toçi ${ }^{2}$, Skender Ahmeti ${ }^{3}$
}

\begin{abstract}
Sažetak
Ovo istraživanje primjenom brojnih metodoloških pristupa pruža empirijske dokaze o izravnavanju prihoda u bankarskom sektoru u devet zemalja jugoistočne Europe (JIE) za razdoblje 2005.-2014. Prvo, korištenjem uzorka od 321 banke, ovaj rad potvrđuje našu prvu hipotezu da banke u regiji Jugoistočne Europe koriste rezervacije za gubitke po kreditima (LLP) kako bi izravnale svoje prihode. Drugo, dijeljenjem rezerviranja za kreditne gubitke na njegove dvije komponente (diskrecijsku i ne-diskrecijsku), ovo istraživanje pruža nove dokaze o učincima komponenata rezervacija za kreditne gubitke na rast bankarskog kreditiranja. Rezultati jasno potvrđuju našu drugu hipotezu da su komponente LLP-a bitne za rast bankarskog kreditiranja. Treće, ovaj rad procjenjuje upotrebu banaka za rezerviranje gubitaka po kreditima za upravljanje kapitalom. Empirijski rezultati ne podupiru hipotezu o upravljanju kapitalom za banke u jugoistočnoj Europi. Za razliku od ostalih istraživanja, novost u ovome radu je uključivanje zemalja jugoistočne Europe..
\end{abstract}

Ključne riječi: rezervacije za gubitke po kreditima, banke Južne i Istočne Europe, izravnanje prihoda, hipoteza o upravljanju kapitalom, diskrecijska komponenta, ne-diskrecijska komponenta.

JEL klasifikacija: G21, M10, M41, M49

1 Asistent, Sveučilište u Prištini "Hasan Prishtina", Ekonomski Fakultet, 10000 Priština, Republika Kosovo. Znanstveni interes: bankarstvo, korporativne financije i institucionalna ekonomija.Tel: +38344 422 122. E-mail: albulena.shala@uni-pr.edu. ORCID ID: https:// orcid.org/0000-0002-8403-4536.

2 Redoviti profesor, Sveučilište u Prištini "Hasan Prishtina", Ekonomski Fakultet, 10000 Priština, Republika Kosovo. Znanstveni interes: financijska ekonomija, bankarstvo, institucionalna ekonomija. Tel.: +38344376 907. E-mail:valentin.toci@uni-pr.edu. ORCID ID: https://orcid.org/0000-0003-1062-918X. (Osoba za kontakt).

3 Redoviti profesor, Sveučilište u Prištini "Hasan Prishtina", Ekonomski Fakultet, 10000 Priština, Republika Kosovo. Znanstveni interes: računovodstvo, menadžersko računovodstvo $i$ računovodstvo troškova., Tel.: +38344313 130. E-mail: skender.ahmeti@uni-predu. 